\title{
Pre-Hispanic settlements in hydrometeorologically susceptible areas during the late Holocene: The Upper Delta of the Paraná River Case
}

The Holocene

2017, Vol. 27(I2) I80I-|8| |

(C) The Author(s) 2017

Reprints and permissions:

sagepub.co.uk/journalsPermissions.nav DOI: $10.1177 / 0959683617708446$

journals.sagepub.com/home/hol

@SAGE

\author{
Carola Castiñeira Latorre,' Eduardo Apolinaire, ${ }^{2}$ \\ Adriana M Blasi, ${ }^{3}$ Mariano Bonomo, ${ }^{2}$ Gustavo Politis, ${ }^{4,5}$ \\ Laura Bastourre ${ }^{2}$ and Florencia Mari ${ }^{6}$
}

\begin{abstract}
In this paper, we present the results of the geoarchaeological studies carried out in two archaeological localities of the Upper Delta of the Paraná River (Argentina). The main objective of these studies is to depict the pre-Hispanic strategies involved in the colonization and settlement of southern South America wetlands. Paraná Delta is one of the most conspicuous areas of these lowlands and comprises a large wetland macrosystem. Its current geomorphological configuration was established after the last transgressive mid-Holocene event c. $6000{ }^{14} \mathrm{C} \mathrm{yr} \mathrm{BP}$. In this environment, a high ecological heterogeneity, with diverse and abundant tropical and temperate biota, was developed. These features were important factors to the human colonization and utilization of these wetlands. However, this environment has the highest hydrometeorological susceptibility of La Plata basin. This susceptibility had an impact on settlement systems and resource exploitation strategies established in the area since at least $2000{ }^{14} \mathrm{C}$ yr BP. These strategies involved at least two settlement types: semi-permanent residential camps and transitory camps oriented to exploit particular resources. The semi-permanent settlements were located in anthropogenic elevated mounds, locally known as 'cerritos', and were not subjected to seasonal inundations. Conversely, the transitory camps are found in levees exposed to recurrent flooding.
\end{abstract}

\section{Keywords}

Goya-Malabrigo, hydrometeorologically susceptible areas, late Holocene, mound building, settlement system, Upper Delta of the Paraná River

Received 22 September 2016; revised manuscript accepted 9 March 2017

\section{Introduction}

The Paraná River Delta is considered a complex estuarine delta influenced by Paraná and Uruguay River risings and the Río de La Plata freshwater tides (see Baigún et al., 2008; Minotti and Borro, 2011; Parker and Marcolini, 1992). This delta constitutes a wide wetland macrosystem which covers more than $17,000 \mathrm{~km}^{2}$ on the final section of the lower Paraná River. It was formed over a mid-Holocene marine littoral complex and started to define its current morphology after the last transgressive event c. $6000{ }^{14} \mathrm{C}$ yr BP (Cavallotto et al., 2004, 2005; Codignotto, 2004; Iriondo and Kröhling, 2008).

This Delta presents a high environmental heterogeneity represented by rich and abundant biota of both subtropical and temperate origin (Blanco and Méndez, 2010; Bó, 2006; Malvárez, 1999). Its landscape is mainly characterized by islands produced by the accumulation of sediments supplied by major Paraná River tributaries (e.g. Bermejo, Paraguay, Pilcomayo) which are transported as suspended sediments (Bonetto and Orfeo, 1984; Rinaldi et al., 2006).

The Paraná River Delta geological history together with its position in the lower section of La Plata Basin is strongly influential in determining the high susceptibility of this area to hydrometeorological phenomena (Herzer et al., 2004; Ré and Menendez,
2004). The Paraná River hydrological regime exhibits throughout the year variations in its water level. High water levels occur from December to April and low water levels between April and

'CONICET, División Mineralogía, Petrología y Sedimentología del Museo de La Plata, FCNYM - Universidad Nacional de la Plata (UNLP), Argentina

${ }^{2}$ CONICET, División Arqueología del Museo de La Plata, FCNYM Universidad Nacional de la Plata (UNLP), Argentina

${ }^{3} \mathrm{CIC}$, División Mineralogía, Petrología y Sedimentología del Museo de La Plata, FCNYM - Universidad Nacional de la Plata (UNLP), Argentina ${ }^{4}$ Facultad de Ciencias Sociales de la UNCPBA, CONICET-INCUAPA, Argentina

${ }^{5}$ División Arqueología del Museo de La Plata, FCNYM - Universidad Nacional de la Plata (UNLP), Argentina

'Laboratorio de Tritio y Radiocarbono (LATYR), CIG, CONICETUNLP, Argentina

\section{Corresponding author:}

Eduardo Apolinaire, CONICET, Departamento Científico de Arqueología del Museo de La Plata, FCNYM - Universidad Nacional de la Plata (UNLP), Paseo del Bosque s/n, La Plata 1900, Argentina. Email: eapolinaire@gmail.com 


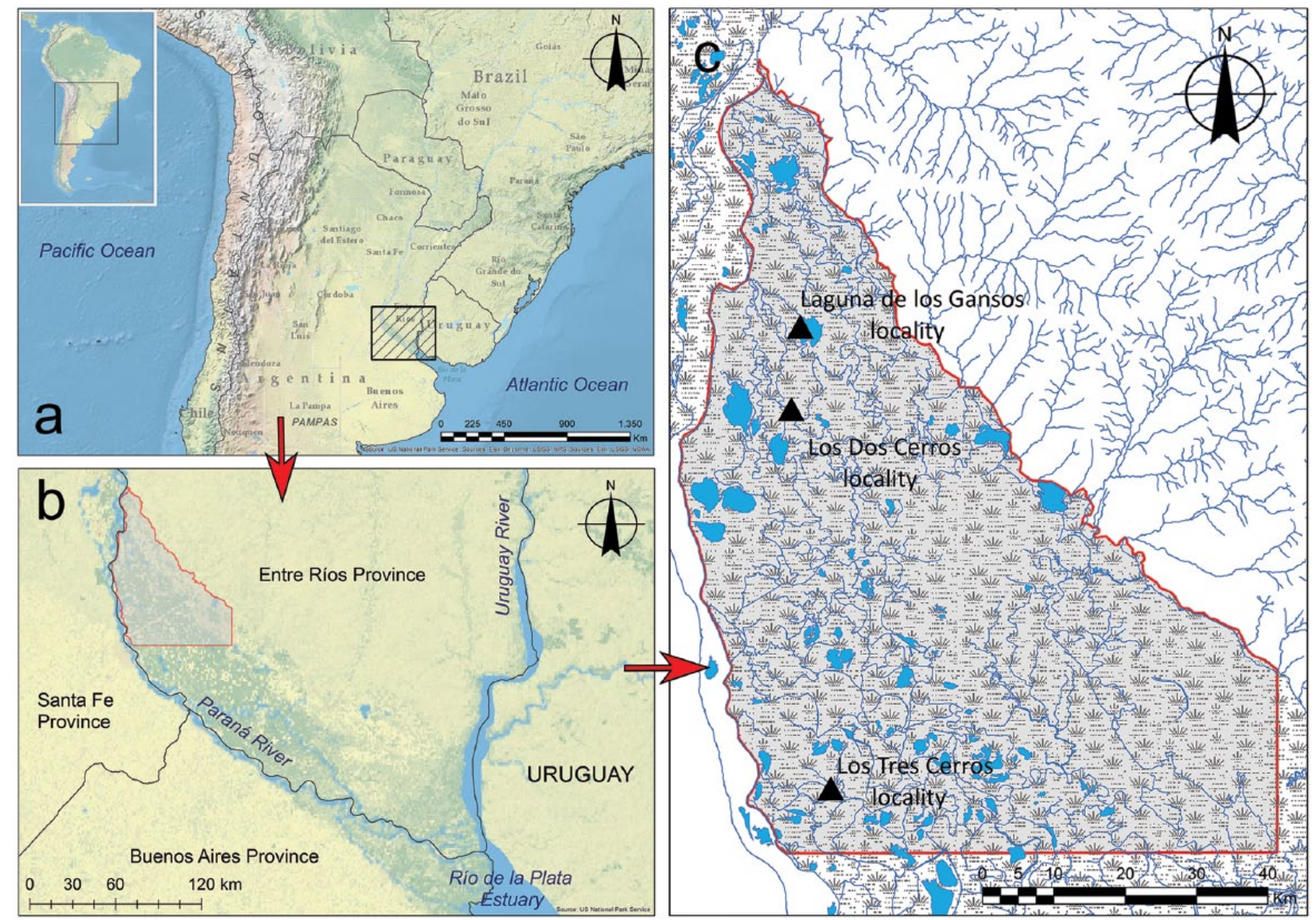

Figure I. (a) Location of the study area, (b) detail of the UDPR and (c) location of archaeological localities considered in this paper.

November (Bó and Malvárez, 1999). Precipitations of great magnitude (which exceed the annual mean of $1000 \mathrm{~mm} / \mathrm{yr}$ ) frequently associated with the El Niño Southern Oscillation (ENSO) climate phenomenon produce extraordinary flood events (Herzer et al., 2004). These deluge episodes affect extensively the deltaic environment (e.g. Camilloni and Barros, 2003) and are influenced by strong windstorms and south-east tidal phenomena as well (Minotti and Borro, 2011; Neiff and Malvárez, 2004). The aforementioned hydrometeorological dynamics sustain the high productivity and biodiversity of these ecosystems (Bó, 2006).

Typically, the Paraná Delta has been divided in two contiguous sectors: the Upper Delta (from the beginning of the littoral complex to the Paraná Pavón River) and the Lower Delta (from Paraná Pavón River to the Río the La Plata estuary). The Upper Delta of the Paraná River (herein UDPR) exhibits a discontinuous relief marked by both positive landforms such as levees, scroll bars, ridges and dunes, and negative ones such as depressions, ponds and shallow streams. Each landform presents a differential vegetal colonization related not only to its genesis and the evolution of its substrata, but also to its specific responses to high water regimes (floods) and the period through which these persist. Variations in high and low water regimes produce significant fauna distribution changes. During floods, the area occupied by mammals such as Blastocerus dichotomus, Hydrochoerus hydrochaeris and Myocastor coypus is limited to the emerging sections of elevated landforms. Parallelly, fish that scattered during flooding events are then, as water retires, ensnared in ponds and shallow streams.

The variable availability of resources and territories related to the hydrometeorological dynamic of the UDPR has been an important factor in the human settlement of this area. According to the radiocarbon chronologies available, this colonization process took place in the late Holocene (Bonomo et al., 2011). In this paper, we present and discuss the archaeological record recovered from two different types of settlements that correspond to the earliest evidence of UDPR occupation. Here, we evaluate whether those records reflect strategies tending to optimize spatial occupation and resource exploitation in environments highly susceptible to hydrometeorological events. Finally, we contribute to the characterization of Goya-Malabrigo archaeological entity, which describes a particular pre-Hispanic sociocultural complex developed in the lower section of La Plata basin (Politis and Bonomo, 2012).

\section{Archaeological background}

Pre-Hispanic mounds are one of the most conspicuous cultural manifestations in the lowlands of South America (Bonomo et al., 2011; Castiñeira et al., 2013, 2014; Durán and Bracco, 2000; Erickson, 2006; Iriarte et al., 2004; Naue, 1973; Ribeiro and Milheira, 2015; Rostain, 2010; Schmitz et al., 1991; Suárez and Gianotti, 2013). Archaeological scholarship about human occupation in UDPR has been focused mainly in the genesis and evolution of these mounds (Castiñeira et al., 2013, 2014; Politis et al., 2011). Archaeological research in this area suggests that the practice of mound building for the development of domestic, productive and ritual activities dates at least from $1000{ }^{14} \mathrm{C} \mathrm{yr}$ BP (Castiñeira et al., 2014). The practice of elevating residencies, corrals, apiaries and orchards continues among the current rural population of the area (Bonomo, 2012; Ceruti, 2003; Gaspary, 1950).

Within our study area (Figure 1), mounds are generally found isolated or in clusters of two or three. Their height ranges between 1.0 and $2.5 \mathrm{~m}$ and their morphology is elliptical with maximum diameters ranging from 35 to $80 \mathrm{~m}$ (Bonomo et al., 2011). One of the most studied areas in terms of the genesis and evolution of 
mound building is Los Tres Cerros (herein LTC) archaeological locality (32 $\left.51^{\prime} 17.3^{\prime \prime} \mathrm{S} / 60^{\circ} 33^{\prime} 37.6^{\prime \prime} \mathrm{W}\right)$, located $40 \mathrm{~km}$ south of the sites assessed in this article (Figure 1). The mounds present in LTC dated to $c .1000{ }^{14} \mathrm{C}$ yr BP (Politis et al., 2011). The results of the study of natural and anthropic sedimentary sequences allow Castiñeira et al. (2013) to propose that mound building in LTC was carried out using a selection of local and allochthonous sediments. These sediments were mixed with ceramics, thermoaltered sediments and organic materials in order to obtain an optimal building mixture for the accretion and consolidation of earthworks. These construction techniques used in LTC and other mounds of the UDPR (Castiñeira et al., 2014) are similar to those found in lowlands of lower Uruguay river, eastern Uruguay and Rio Grande do Sul state in Brazil (Bracco et al., 2000; Castiñeira et al., 2015; Castiñeira and Piñeiro, 2000; López Mazz, 1992; Salles Machado, 2005).

Mound building has been one of the main characteristics used in the delimitation of Goya-Malabrigo archaeological entity (Ceruti, 2003; Politis and Bonomo, 2012). This entity was defined by morphological and stylistic traits of pottery, specialized technologies for the exploitation of aquatic resources, small-scale farming and building of mounds or 'cerritos'. It span over the second part of the late-Holocene and its spatial distribution includes the mid-alluvial plain and the delta of the Paraná River, the Lower Uruguay River and the left margin of the Río de La Plata (see Politis and Bonomo, 2012).

Thus far, our geoarchaeological research focused on the genesis and evolution of anthropic mounds (Castiñeira et al., 2013, 2014; Politis et al., 2011). Recently, we began to study other sites located on naturally elevated landforms (Bonomo et al., 2016). The sedimentary and archaeological records of Laguna de los Gansos (herein LDLG), located in a long fluvial levee, and Los Dos Cerros (herein LDC), with two anthropic mound sites (LDC1 and LDC2), will be evaluated and discussed. We analyse both site types (levee and mounds) through sedimentary sequences, archaeological record and preservation conditions.

Based on the results obtained from the study of natural topography and anthropic mounds, we propose earlier dates for earthworks in UDPR. We also evaluate the hypothesis that different occupation strategies such as mound building and occupation of natural landforms were components of a settlement system oriented to exploit local resources. This strategy allowed past populations to cope with changing environmental conditions generated by the high hydrometeorological susceptibility of the microregion.

\section{Features of the study area}

Our study area is located in an island area of the UPDR (Figure 1). Suspended sediments transported by the Paraná River and accumulated in the form of sand, clay and silt banks formed these islands (Bonetto and Orfeo, 1984; Rinaldi et al., 2006). The development and stabilization of these banks are also related to the accumulation of plant remains, which favours the accretion of sediments (Ramonell et al., 2011). As water level drops, these deposits are colonized by vegetation which promotes soil development (Vizia et al., 2010). Simultaneously, the vegetation stabilizes the island margins and fixes the position of adjacent river channels. Once the islands stabilize, successive channel floodings contribute to the development of elongated levees, which are subsequently covered by gallery forests. During extraordinary flood events, levees are fragmented by crevasse channels. In this case, water and sediments are delivered into the depressed central areas of the islands developing shallow lentic environments. Repeated flooding can enlarge the crevasse channels and split the island into smaller fragments (Cavallotto, 1995; Drago et al., 2014; Ramonell et al., 2011). This dynamic creates sedimentarily, ecologically and topographically diverse environments. In this regard, the study area is characterized by the presence of levees colonized by mixed fluvial forests, while grasslands dominate medium sized topographies and grasses and other wetland plants dominate the lowest areas (Malvárez, 1999). Flood pulses together with plant community variability in emerging and submerged areas create considerable faunal diversity (Quintana and Bó, 2010; Vizia et al., 2010).

Archaeologically, the area is marked by the presence of preHispanic cultural surface and subsurface deposits on levees and anthropic mounds. LDLG locality includes LDLG1 $\left(32^{\circ} 29^{\prime}\right.$ 59.3" S/60 38'19.7" W) and LDLG2 (32 $22^{\prime} 38.6^{\prime \prime} \mathrm{S} / 60^{\circ} 38^{\prime} 25.4^{\prime \prime}$ $\mathrm{W})$ sites, which are placed in a natural levee system (Figure $2 \mathrm{a}-\mathrm{c})$. LDLG is circumscribed to the east by shallow lentic environments characteristic of the area (Los Gansos Lake) and to the west by the Timbó Colorado stream, tributary of the Paraná River (Figure 2a). Anthropic mounds are studied in LDC archaeological locality, placed $3 \mathrm{~km}$ south of LDLG. We present preliminary results of the analysed sedimentary successions of LDC1 (32 31'33.5" S/60³7'39" W) and LDC2 (32 $31^{\circ} 31.7^{\prime \prime}$ $\mathrm{S} / 60^{\circ} 37^{\prime} 41.4^{\prime \prime} \mathrm{W}$ ) mounds (Figure $2 \mathrm{a}$ and d).

\section{Materials and methods}

The LDLG1 site was examined using artificial levels of $5 \mathrm{~cm}$ to a depth of $1 \mathrm{~m}$ (Figure $2 \mathrm{~b}$ ). To evaluate the continuity of the sedimentary sequence, a soil augering was utilized to reach $3 \mathrm{~m}$ in depth. For the LDLG2 site, the same artificial levels of $5 \mathrm{~cm}$ to 1 $\mathrm{m}$ were employed (Figure 2c). For the highest elevations of the LDC1 and LDC2 mounds (Figure 2d), the stratigraphy was examined using artificial levels of $10 \mathrm{~cm}$ to $1.5 \mathrm{~m}$ depth and then soil augering to $3 \mathrm{~m}$ in depth to determine basal deposits. In order to map the topography of the sites and the geomorphological features of the area, a survey with Total Station Nikon Nivo 5C was done (Figure $2 \mathrm{~b}-\mathrm{d}$ ).

Stratigraphy exposed in excavation profiles and test pits was differentiated in terms of colourimetric characteristics (Munsell colour chart), and textural and compositional features (presence or absence and concentration of archaeological materials, root activity and concretions). These parameters were also used in soil augering samples. Subsequently, they were subjected to sedimentological analysis (grain size, mineral composition), preliminary biocompositional observation (biogenic silica content) and chemical ( $\mathrm{pH}$ and $\%$ organic matter) analyses.

Grain size analyses were performed according to standard methodology, with sieve size intervals of one phi for gravel and sand fractions, and the International Pipette Method for silt and clay (Carver, 1971; Day, 1965). Fractions retained in sieves of 2-0.062 mm were then observed with a binocular magnifying glass. Percentages of sand, silt and clay content were determined using Folk's grain size classification (1954). Mineral composition in very fine sand fraction was studied using loose grain slides and a petrographic microscope. The mineralogical examination was also carried out for the total sample by employing a Diffractometer Philips PW 3710 to perform an x-ray diffraction (XRD). The argilomineral composition in natural, glycolated and calcined oriented preparations was evaluated using XRD.

The sedimentary samples were examined for qualitative determination of bioclastic composition through a standard procedure modified by Zhao and Pearsall (1998). Carbonates were removed with $\mathrm{HCl}(35 \%)$ and organic matter was treated with hydrogen peroxide $(30 \%)$ and dispersed by way of ultrasound together with sodium hexametaphosphate $(4 \%)$. While the sand fraction was extracted by sieving, the clay fraction was separated by decanting. Finally, permanent slides were prepared and Biogenic Silica content was determined through previous research in the study area carried out by Castiñeira et al. (2013) and Sánchez et al. (2013). 

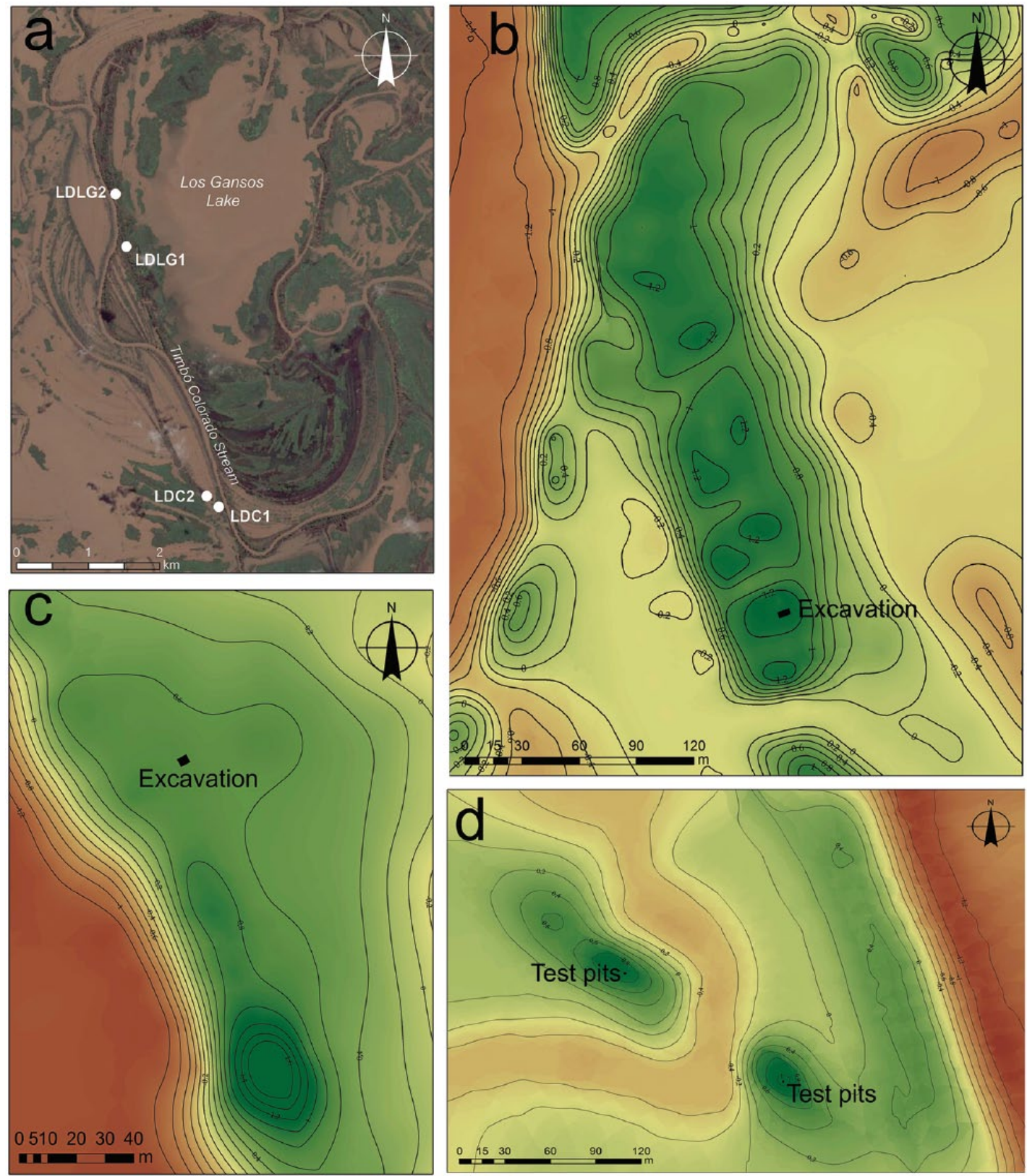

Figure 2. Location and topographic detail of the studied localities: (a) area where archaeological sites are located, (b) topographic survey of LDLGI site, (c) topographic survey of LDLG2 site and (d) topographic survey of LDC mound sites.

Organic matter and carbonate content estimates were computed following the adjusted protocol established in Heiri et al. (2001), after applying the ignition method (analytical LOI). For determining $\mathrm{pH}$ levels, Potentiometric Titration methodologies (Bates, 1983; Willard et al., 1974) were used with the support of a LUTRON pH-222 pH meter. Conventional radiocarbon dates were calculated in the Laboratorio de Tritio y Radiocarbono (LATYR-CONICET-CIG-UNLP) and AMS was performed in the NSF-Arizona AMS Laboratory. The dates were calibrated with Calib 7.1 using ShCal13.14c calibration curve (Hogg et al., 2013).

\section{Results}

\section{Archaeological results}

LDLG1 is located in a levee, which has a length of $142 \mathrm{~m}$ and a height of approximately $1.20 \mathrm{~m}$ with respect to the surrounding plain. Its north and south flanks are defined by overflow channels (Figure 2b). Excavations involved a total of $44 \mathrm{~m}^{2}$ divided into two sectors $\left(8 \mathrm{~m}^{2}\right.$ and $\left.36 \mathrm{~m}^{2}\right)$. Archaeological materials were recovered from a depth of 0.05 to $\sim 0.40 \mathrm{~m}$. Pottery and archaeofauna are the most abundant materials in the site. The pottery sample analysed thus far is composed of 4711 sherds. The majority $(82.36 \% ; n=3880)$ are fragments of bodies/bases of vessels and $16.55 \%(n=780)$ correspond to rim fragments. The remaining objects consist of unfired and fired clay masses, appendices, handles and unidentified fragments. The analysed archaeofaunal assemblage comprises a total of 1294 remains. It is characterized by the high frequency of Myocastor coypus (coypu) followed by Hydrochoerus hydrochaeris (capybara) and Blastocerus dichotomus (marsh deer), of which the latter is particularly significant within the collection because of its biomass. Other mammals, such as carnivores, are poorly represented within the sample yet exhibit significant taxonomic diversity and, in some cases, show evidence of anthropic utilization. The high frequency of Blastocerus dichotomus and the scarcity of fish in comparison to other sites in the area is a remarkable aspect of inter-site variability within the area. While fish constitute about $80 \%$ of the NISP, cervidae are only represented within the artefactual assemblage in the LTC1 site (Bastourre, 2014). In this regard, botanical and faunal studies at LDLG1 suggest that the 
Table I. Radiocarbon dates mentioned in the text.

\begin{tabular}{|c|c|c|c|c|c|c|}
\hline Site & Sample ID & Deep $(m)$ & Dated material & Laboratory code & Date ${ }^{14} \mathrm{C}$ (yr BP) & $\begin{array}{l}\text { Calibrated age (years } \\
\text { AD, range } I \sigma / 2 \sigma)\end{array}$ \\
\hline \multirow[t]{3}{*}{ LDLGI } & S4 N2 & 0.15 & Faunal bone & AA-10390I & $|775 \pm 5|$ & {$[246: 36 \mid] /[|48: 4| 7]$} \\
\hline & S3 N3 & 0.20 & Faunal bone & AA-98847 & $1236 \pm 46$ & {$[770: 892] /[689: 971]$} \\
\hline & S4 N4 & 0.25 & Archaeofauna bone & AA-98845 & $1740 \pm 47$ & {$[252: 406] /[148: 417]$} \\
\hline \multirow[t]{2}{*}{ LDLG2 } & Individual I & 0.40 & Human bone & AA-9885I & $570 \pm 43$ & {$[1396: 1436] /[1320: 1450]$} \\
\hline & Individual 2 & 0.40 & Human bone & AA-103899 & $590 \pm 46$ & {$[1326: 1430] /[1310: 1447]$} \\
\hline $\mathrm{LDCl}$ & $\mathrm{LDCl}$ & 210 & Sediment & LP-3।38 & $1940 \pm 80$ & {$[25: 213] /[-67: 339]$} \\
\hline LDC2 & LDC2 & 115 & Sediment & LP-3| 30 & $1170 \pm 60$ & {$[862: 994] /[772: 1021]$} \\
\hline
\end{tabular}

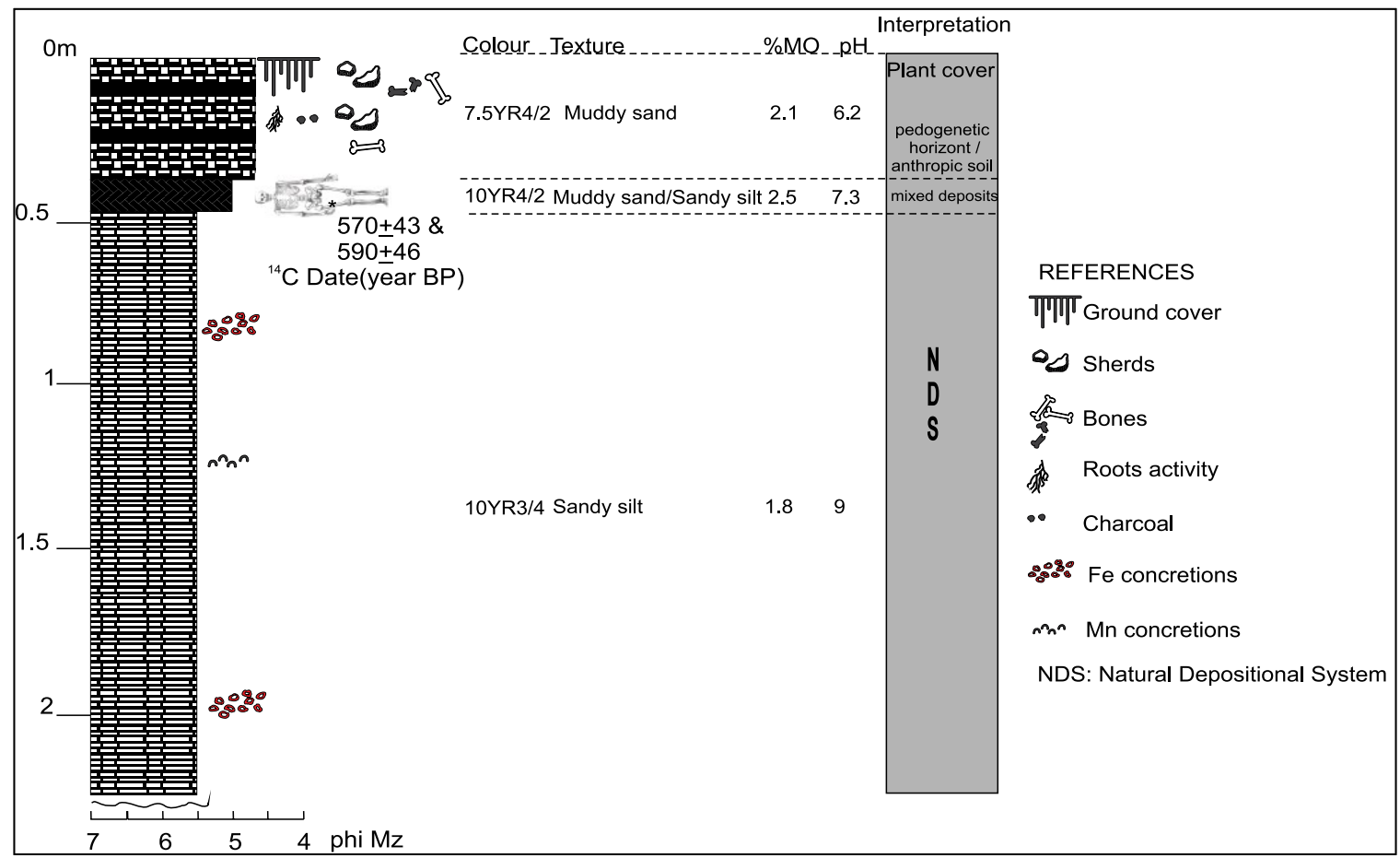

Figure 3. LDLG2 stratigraphic record.

inhabitants of this settlement engaged in a mixed economy based on wildlife resources possibly complemented by crops (e.g. Zea mays microscopical remains) (Colobig et al., 2014). Meanwhile, three radiocarbon dates attained by means of AMS place the occupation of LDLG1 between 1775 and $1236{ }^{14} \mathrm{C}$ yr BP (Table 1). These dates were obtained from faunal remains exhibiting clear evidence of processing.

LDLG2 is located $660 \mathrm{~m}$ north of LDLG1 at the same levee (Figure 2c). Today, this site is at the entrance of a livestock corral adjacent to a small rural settlement. The excavated area covers 17 $\mathrm{m}^{2}$. Abundant pottery, faunal remains and charcoal were recovered from the first $0.30 \mathrm{~m}$ of the A Horizon (Figure 3). A zoomorphic pottery handle (possibly the head of a mammal) and an appendix with the shape of a bird head (psittacidae) were found here. Between 0.35 and $0.45 \mathrm{~m}$ depth, at the transition between the A Horizon and the underlying sandy deposit, two incomplete human burials and isolated human bones were found. The burial evidence of Individual 1 (male, young adult, 22-26 years old) yielded a date of $570 \pm 43{ }^{14} \mathrm{C}$ yr BP (Table 1). It consists of an incomplete skeleton with the pelvic bone, lower articulated legs and a cranium placed over the pelvis. Individual 2 (possibly an adult), dated to $590 \pm 46{ }^{14} \mathrm{C}$ yr BP (Table 1), is a complete, primary burial in extended dorsal position. The posterior bones of the skull were recovered in a sediment with abundant charcoal particles and fish remains. Because both burials were subjected to site formation processes occurring at the superficial horizons in the entrance to a livestock corral, all human remains are poorly preserved and extremely fragmented.

Finally, LDC1 mound has a height of $1.15 \mathrm{~m}$ and a maximum diameter of $31 \mathrm{~m}$. In the case of LDC2 site, the mound reaches a height of $1.20 \mathrm{~m}$ with respect to the surrounding plain and has a maximum diameter of $23 \mathrm{~m}$. The two mounds are $90 \mathrm{~m}$ apart and separated by a shallow stream (Figure 2a). Test pits of $50 \times 50 \mathrm{~cm}$ and $150 \mathrm{~cm}$ depth were performed in the epicentres of both structures and then deepened by soil augering to determine the basal deposits (Figure 2d). LDC1 archaeological materials, primarily represented by pottery fragments and faunal remains, reached a depth of $2 \mathrm{~m}$ (Figure 4). In contrast, at LDC2 mound, the same materials only extended as deep as $1.20 \mathrm{~m}$ (Figure 4). From the basal deposits containing cultural material two radiocarbon dates were obtained, yielding ages of $1940 \pm 80{ }^{14} \mathrm{C}$ yr BP and $1170 \pm$ $60{ }^{14} \mathrm{C}$ yr BP for LDC1 and LDC2 sites, respectively (Table 1).

\section{Geoarchaeological results}

The stratigraphic record of LDLG1 begins with dark grey sediments $(2.5 \mathrm{YR} \mathrm{4/2})$ with a muddy texture (3-2.20 m depth) followed by dark brown (10 YR 3/4) sandy-silt sediments (2.20-0.45 $\mathrm{m}$ depth) (Figure 5). The mineralogy of the basal deposits sample is dominated by the presence of clasts of quartz, mica, opaque minerals (haematite) and plagioclase. This mineral association was confirmed by XRD analysis (Figure 6a and c). The clay 


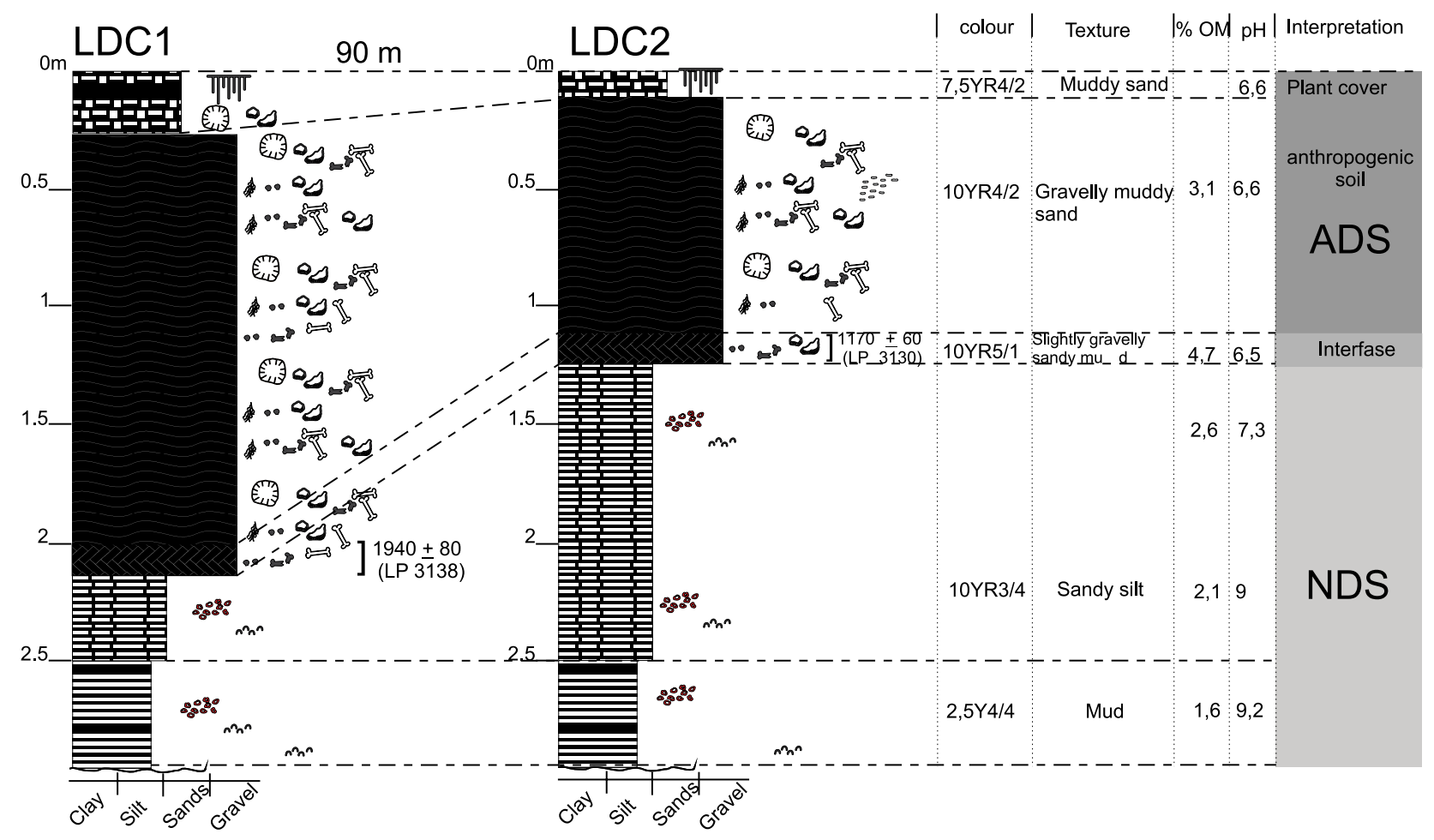

REFERENCES. NDS: Natural depositional system, ADS: Anthropic depositional system.

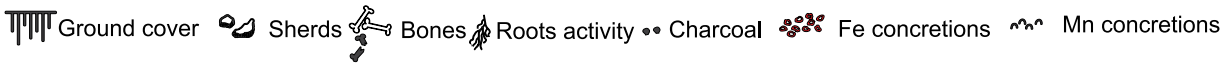

Figure 4. Stratigraphic record of LDCI and LDC2 mounds.

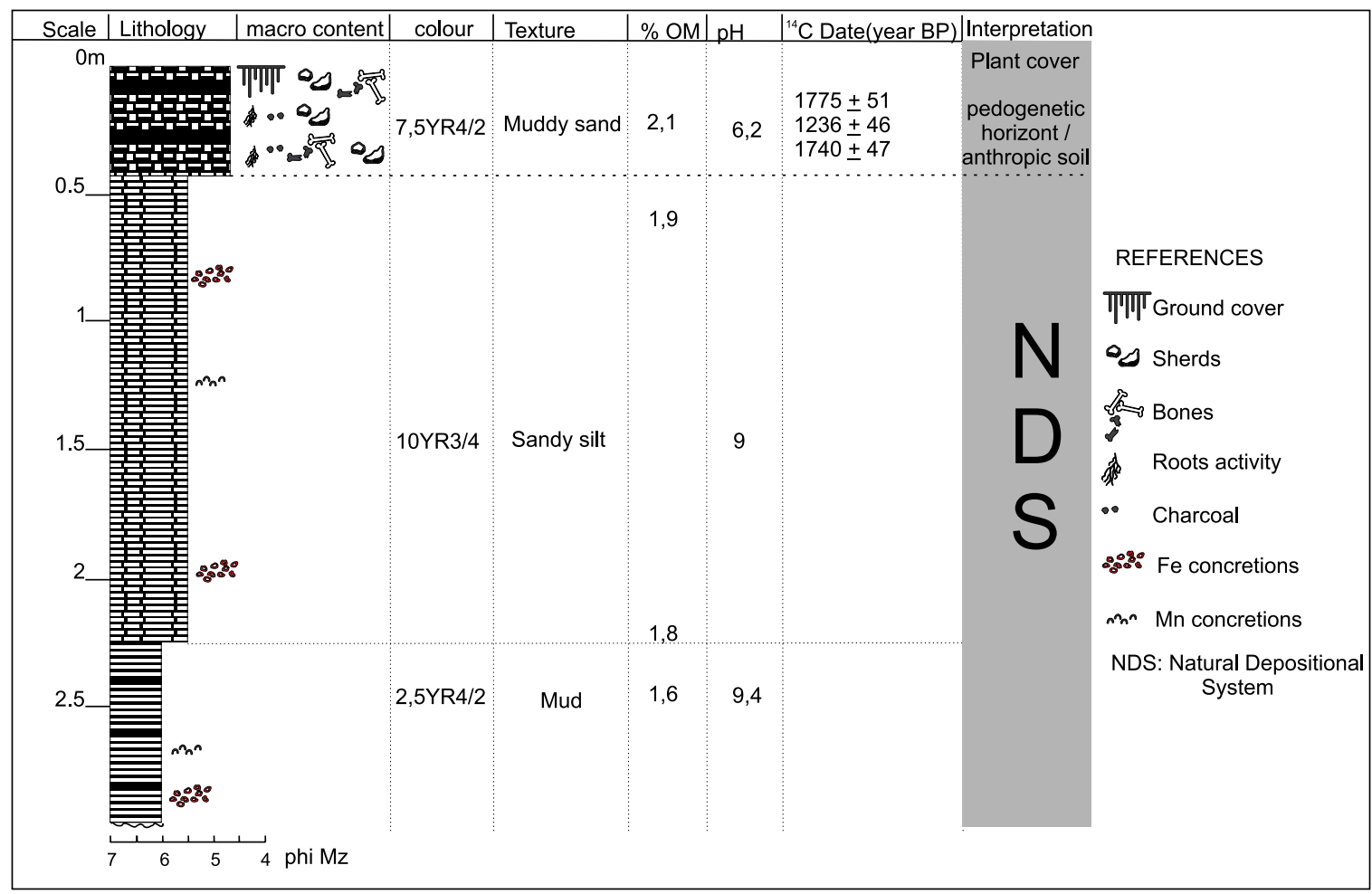

Figure 5. LDLGI stratigraphic record.

association of these basal deposits is characterized by smectite, illite and kaolinite/chlorite (Figure 6b). Furthermore, the bioclastic composition observed is dominated by the presence of phytoliths (Figure 6e), sponge spicules (Figure 6f) and some diatom frustules which are generally fragmented (Figure $6 \mathrm{~g}$ ). Organic matter concentration for these deposits has percentages of approximately $2 \%$, while the $\mathrm{pH}$ values suggest an extremely alkaline to slightly alkaline profile (Figure 5).

The uppermost deposits supporting the present groundcover (A Horizon) are muddy-sand sediments with greyish dark brown colour (7.5 YR 4/2) (Figure 5). The sand and clay fraction of the upper deposits are similar to the basal ones (Figure 6a and b). 
a

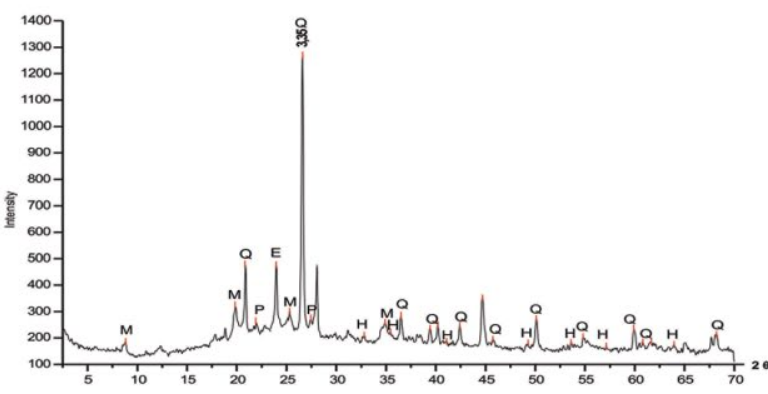

C

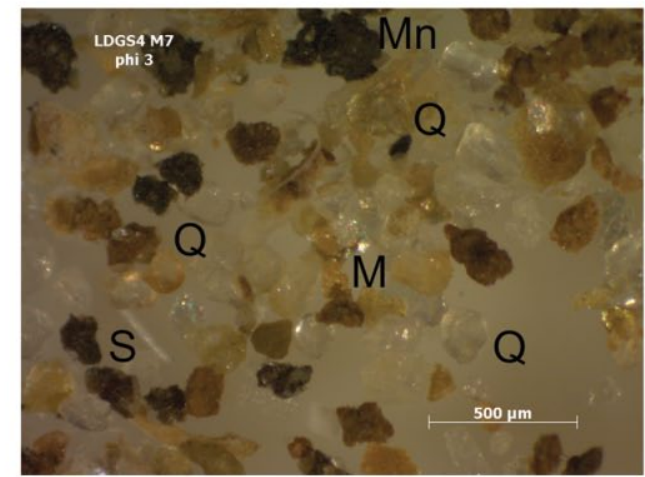

e
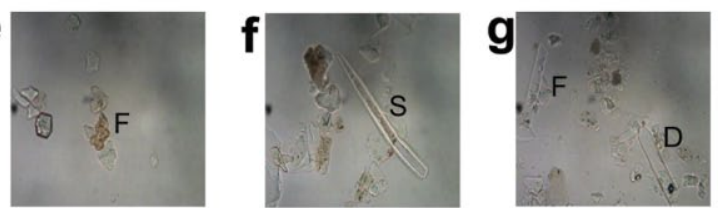

b

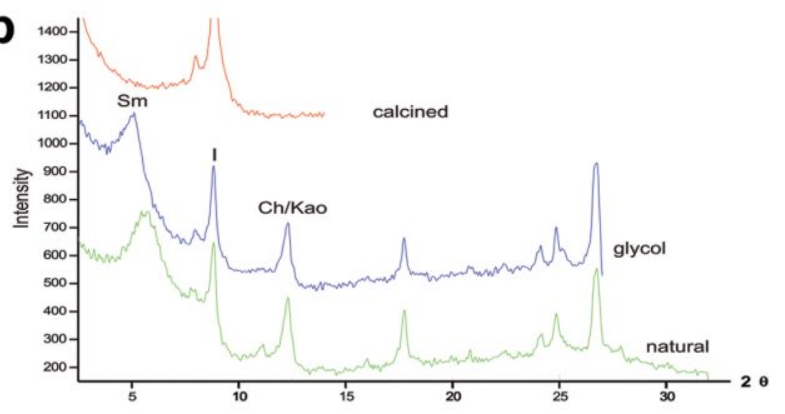

d

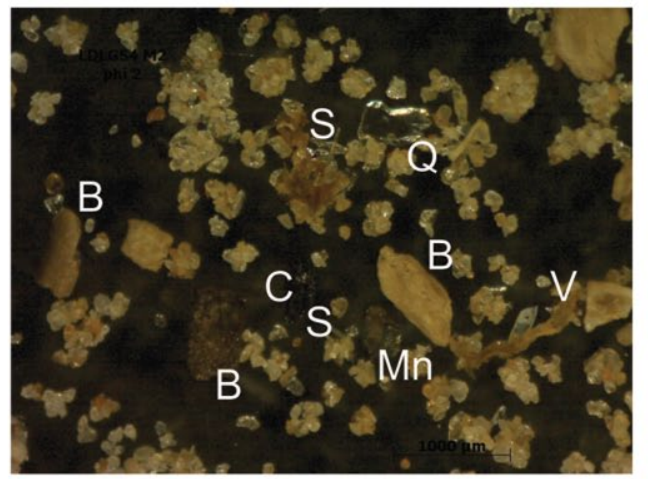

h
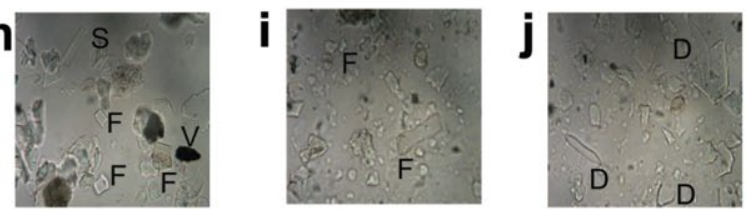

Figure 6. Mineral and bioclastic compositional results in the LDGI sedimentary samples. (a) XRD results for total-rock sample; (b) XRD results for clay fraction sample; (c) sand fraction composition in basal deposit samples; (d) sand fraction composition in upper deposit samples; (e), (f) and (g) bioclastic composition in basal deposit samples; (h), (i) and (j) bioclastic composition in upper deposit samples. References: $M$ = Muscovite, $\mathrm{Q}=$ Quartz, $\mathrm{P}=$ Plagioclase, $\mathrm{E}=$ error, $\mathrm{H}=$ haematite, $\mathrm{Sm}=$ Smectite, $\mathrm{I}=\mathrm{Illite}, \mathrm{Chl} / \mathrm{Kao}=$ chlorite/kaolinite, $\mathrm{Mn}=$ manganese concretion, $S=$ spicula, $B=$ bone, $C=$ charcoal particles, $F=$ phytoliths, $D=$ diatoms, $V=$ vegetable fibre.

Nevertheless, the sand fraction of the upper deposit has bone and charcoal, fish scales and thermo-altered sedimentary lumps (Figure 6d). In regard to the bioclastic composition, an increase in the representation of graminoid phytoliths, sponge spicules and diatom content can be observed (Figure $6 \mathrm{~h}-\mathrm{j}$ ). They also present a better preservation in contrast to those previously described for basal deposits. Organic matter percentages are higher $(2.12 \%)$ than those obtained in basal deposits. However, $\mathrm{pH}$ values recorded for these upper deposits are characterized as slightly acidic. These results may be in line with postdepositional alterations identified in the archaeofaunal assemblage such as low degree of weathering, sedimentary abrasion, elevated root activity and diagenetic alterations observable in crystallinity and bone porosity. According to Silva's observations (2014), some sherds recovered from this upper deposits show postdepositional alterations in one or both faces such as roundness, small superficial detachments and root marks.

The stratigraphic record exposed during the excavation of LDLG2 (Figure 3) is marked by sandy silt textured basal deposits of dark brown tonalities (10YR3/4) similar to those of LDLG1 basal deposits (Figure 5). The A Horizon at LDLG2 has a muddysand texture with brownish dark grey tonalities similar to those observed in LDLG1 (10YR4/2). As mentioned previously, all cultural materials recovered from this site were found within the first $30 \mathrm{~cm}$ of the upper deposits. On the other hand, human bone remains were recovered from the interface between the muddysand deposits and the sandy-silt top of the basal deposit (Figure 3 ). For the sample collected from the sedimentary matrix associated to the burials, a $\mathrm{pH}$ value of 7.3 was obtained.

Stratigraphic records of LDC1 and LDC2 begin with light brown and olive (2.5 Y 4/4) mud deposits which are archaeologically sterile (Figure 4). The sand fraction of these basal deposits is dominated by the presence of clasts of quartz, mica and $\mathrm{Fe}$ and $\mathrm{Mn}$ concretions. The bioclastic sample taken from these basal deposits is dominated by graminoid phytoliths, followed by sponge spicules and very scarce diatom content. $\mathrm{pH}$ values of basal deposits show a strong alkaline environment with little organic matter $(1.66 \%)$. In the case of LDC1, basal deposits are buried under $0.40 \mathrm{~m}$ of dark yellow to light brown (10 YR 3/4) sandy-silt deposits. Conversely, in the case of LDC2, the latter extended for more than $1 \mathrm{~m}$ in the profile. In both cases, silico and bioclastic composition are similar to those of the basal deposits previously described. These deposits evidence an intense alkalinity and low organic content (2\%) and no archaeological remains were found.

Overlying the sandy-silt deposits, the sequence is prolonged by the presence of an interfacial layer, approximately $0.10 \mathrm{~m}$ thick, in both LDC1 and LDC2. The sedimentary matrix of such layer can be classified as grey in colour (10 YR 5/1) and slightly gravelly sandy mud in texture (Figure 4). The gravel fraction of these samples presents thermo-altered sedimentary lumps, charcoal remains, small sherds, bones, fish scales and abundant Fe and Mn concretions. Microscopic observations allowed the recognition of an increase in the amount of phytolites which also show higher degrees of morphotype diversity. Sponge spicules and diatoms increase its quantity as well. No apparent mineralogical differences between overlying and basal deposits could be found.

In LDC1 and LDC2 sites, an archaeological rich deposit of gravelly muddy-sand texture and greyish light brown tonalities (10 YR 4/2) can be found towards the surface (Figure 4). It was in these upper portions of both sequences that cultural materials 


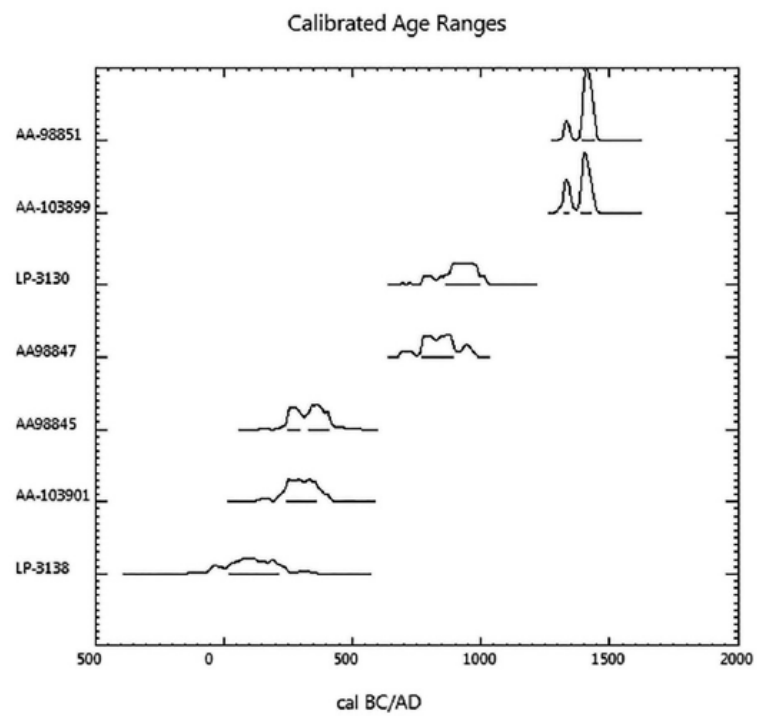

Figure 7. Calibrated ages ranges calculated for LDLG and LDC dates.

such as potsherds, bone instruments and archaeofaunal remains where recovered from test pits. For these deposits, organic matter content is around $3 \%$. The components observed in the gravel fraction are similar to those described for the interfacial deposits. However, the gravel content is more abundant, has bigger components and presents haematite lumps. The sand fraction, on the other hand, presents the same components but they are smaller and associated with clasts of quartz, mica and Fe-Mn concretions. Finally, graminoid phytoliths and, to a lesser extent, spicules make up the biogenic silica content of these deposits. Although diatom representation is minor when compared with the other elements, it is still greater and more diverse than in any other deposit analysed.

To determine the basal age of both mounds, radiocarbon samples (LP-3138 and LP-3130, Table 1) were collected from the organic fraction preserved in the interfacial layers (Figure 4). These layers represent the transition between the natural surface over which the two mounds were erected and the first anthropic depositional events which characterize them. According to the dating (Figure 7), the LDC1 structure began to be constructed $c$. $1900{ }^{14} \mathrm{C}$ yr BP (LP-3138 in Table 1), time period which coincides with the earliest occupation record for LDLG1 (AA-103901 and AA-98845). Around 800 years later, c. $1170{ }^{14} \mathrm{C}$ yr BP (LP-3130, Table 1), the building of the LDC2 mound began, while the latest recorded occupation of LDG1 occurred (AA-98847 in Table 1). Based on the limited number of dates, the contemporaneity of both mound occupations cannot be established. Nevertheless, considering the chronological record obtained for the human remains in LDLG2 (AA-98851 and AA-103899), the occupational history shows a certain degree of continuity (see Figure 7).

\section{Discussion}

Geoarchaeological results obtained for the localities LDLG and LDC allow us to define two depositional systems for the studied area: a natural depositional system (NDS) and an anthropic depositional system (ADS) (Figures 3-5). In this study, NDS is constituted by deposits of fluvial origin (mud, sandy silt and muddy sand). The fluvial processes have formed levees whose deposits make up the sediments of LDLG1 and LDG2 sites, and the basal section of LDC1 and LDC2 mounds. The ADS is represented by gravelly muddy-sand deposits, only present in LDC1 and LDC2 top layers. These deposits, which overlie the NDS, conform to the bulk of the mound sites (Figure 4).
The archaeological record of LDLG1 and LDLG2 sites was recovered from the upper part of the levee. The pedogenetic development of these deposits is evidenced in sedimentary textural alterations (from sandy silt to muddy sand). They also present a high organic content and, consequently, an incremented acidification, which is correlated to metabolic processes of root and microbiologic activity. In addition, such pedological processes might have been favoured by the input of discarded materials resulting from human activities carried out during the occupation. Both sites (LDLG1 and LDLG2) could be classified as 'shallow sites' sensu Zárate et al. (2002). According to these authors, shallow sites represent contexts where the burying of cultural materials could have resulted from the pedological dynamics, which determine low degrees of chrono-stratigraphic resolution. The aforementioned characteristics are also consistent with the chronological resolution obtained for LDLG1, where statistically differentiable ages (e.g. AA-98847 and AA-98845 vide Table 1 and Figure 7) share stratigraphic positioning (Figure 5). Similarly, preservation conditions of pottery and postdepositional alterations observed in faunal remains recovered from LDLG1 suggest exposure to floods (e.g. sedimentary abrasion and/or roundness) followed by a fast burial (e.g. low weathering) of archaeological materials which were subsequently subject to pedological (e.g. acidification and recrystallization) and biostratinomic (e.g. root marks) processes affecting superficial horizons.

ADSs have been defined by Castiñeira et al. (2013) to understand the genesis and evolution of the mounds present in the UDPR. An ADS is produced by a set of intentional human activities tending to build a sedimentary sequence which constitutes a new landform in the landscape. The most salient building activities identified in UDPR are the selection and transport of natural sediments, the incorporation of coarse-sized materials in order to modify the physical properties of these sediments, and the addition of organic and inorganic elements to homogenize them and modify their chemical and binding properties. The UDPR ADSs are characterized by coarser textures (gravelly muddy sand to slightly gravelly muddy sand) in comparison to natural deposits. This coarse-sized clasts (gravel and coarse sands) added to the natural sediments (muds) correspond to fragments of pottery and lumps of burned earth. In sum, these elements were added to give the natural available material greater volume and structural strength in order to build more durable earthworks (Bracco et al., 2000; Castiñeira et al., 2013, 2014, 2015; Castiñeira and Piñeiro, 2000; López Mazz, 1992; Salles Machado, 2005).

Based on cultural intention to modify sediment properties, Edith (1985) distinguishes between anthropic and anthropogenic soils. The former would be constituted by anthropically modified sediments resulting from the development of several activities performed during human occupation. This type of anthropic modification incorporates organic matter, favouring pedological processes. In the study case presented here, anthropic soils would be represented by LDLG1 and LDLG2 upper deposits (Figures 3 and 5). In contrast, anthropogenic soils are composed of natural sediments which were intentionally modified for construction and productive purposes. Accordingly, ADSs such as those recorded for LDC1 and LDC2 comprise a succession of anthropogenic deposits likely to be spatial and temporally individualized.

Despite the preliminary character of LDC locality data, chronological information and archaeological materials studied in other UDPR earthworks support the interpretation that the mounds are residential settlements that underwent prolonged occupations interrupted by abandonment events and subsequent re-occupation (Politis et al., 2011). Occupation of the mounds could have been disrupted by severe flooding which reduce dry living space.

Archaeofaunal and palaeobotanical research conducted at LTC mounds documents a generalized exploitation of natural resources characteristic of fluvial environments, complemented 


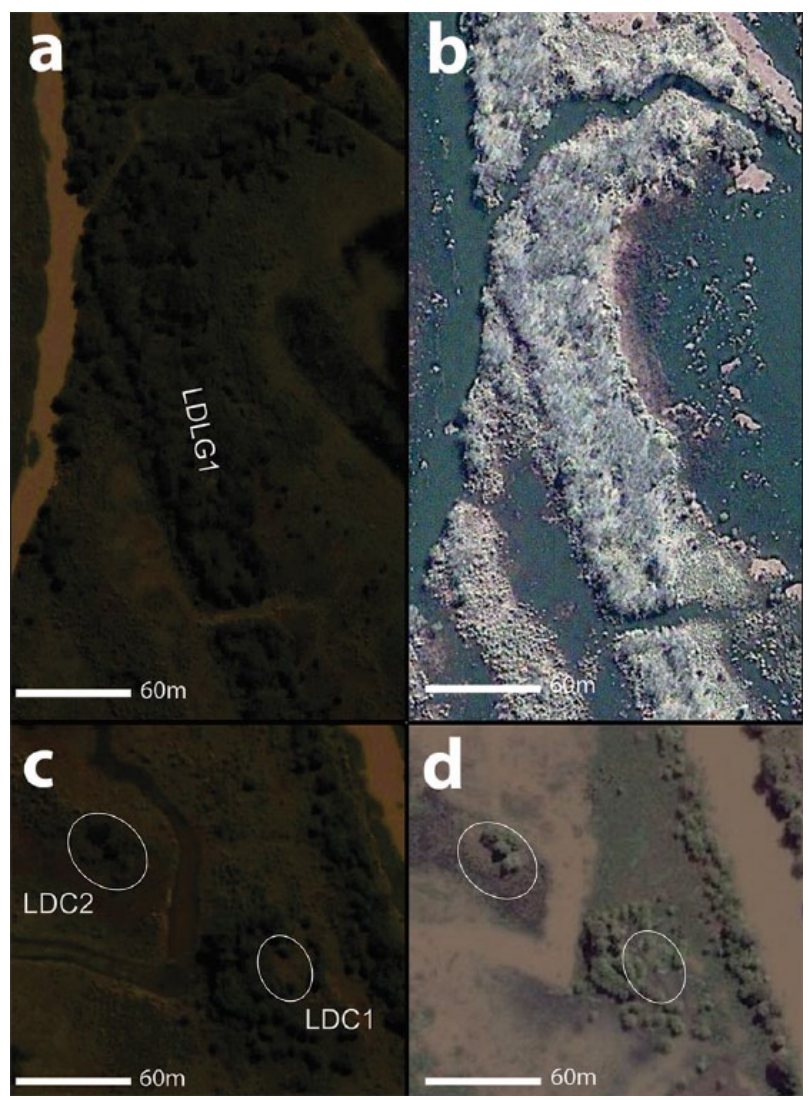

Figure 8. Available settlement space changes during high and low water periods. (a) satellite image of the LDLGI site during a period of low water level (Google Inc., image date: 29/3/20I3, last accessed: I I/02/20 I6); (b) satellite image of the LDLGI site during a period of high water level (Google Inc., image date: 24/7/2013, last accessed: II/02/2016); (c) satellite image of the LDCI and LDC2 mound sites during a period of low water level (Google Inc., image date: 29/3/20I3, last accessed: II/02/2016); and (d) satellite image of the $\mathrm{LDCl}$ and LDC2 mound sites during a period of high water level (ESRI Inc., image date: I3/3/20I0, last accessed: II/02/2016).

by some cultivated species (Colobig et al., 2015; Sánchez et al., 2013). The archaeofaunal record reflects the recurrent exploitation of small- and medium-sized animals, such as rodents and fish, which are abundant, easy to locate and predictable (Bastourre, 2014). The pottery record shows the manufacturing of numerous types of vessels involved in both domestic and ritual activities (Di Prado, 2015; Scabuzzo et al., 2015).

The archaeofaunal assemblage of LDLG1 suggests the exploitation of medium- to large-sized resources (Blastocerus dichotomus, Hydrochoerus hydrochaeris and Myocastor coypus). In contrast to mound occupations, LDLG1 levee exhibits abundant remains of Blastocerus dichotomus (marsh deer) and scarce ichthyofauna. As previously mentioned, LTC mounds provide clear evidence of fish exploitation but cervids are virtually absent from faunal remains. In other words, fishing activities were one of the main subsistence practices at LTC but it was not significant at LDLG1. Levee settlements were occupied during seasonal low water phases, moments in which dry spaces become available. The analysis of LDLG1 pottery suggests an expedient manufacture and decoration of vessels (Silva, 2014). In sum, the abovementioned evidence implies that LDLG1 represents a temporary occupation oriented to the exploitation of local resources. As evidenced in recent satellite images, variations in water level could have conditioned the permanence of occupation in the studied sites (Figure 8). The image documents which location remained above water during 2013 flooding. While LDC mounds remained unflooded (see Figure 8c and d), LDG1 levee was inundated during that same event (see Figure 8a and b). Geomorphological analyses show that these same hydrological and morphological processes probably occurred during the pre-Hispanic human occupation of the UDPR (Cavallotto et al., 2004; Iriondo, 2004). A similar settlement pattern has been noted in the Laguna del Castillo basin in eastern Uruguay (Capdepont et al., 2016; Capdepont and Pintos, 2006; Piñeiro et al., 1999). In these lowlands, mounds are located in elevated areas and were semi-permanently occupied. There are also evidences of temporary camps oriented to the exploitation of specific resources, which are often located in relation to high landforms developed in lagoon margins.

\section{Conclusion}

Based on the earliest chronological records obtained for LDLG1, which is approximately contemporaneous with the beginning of the LDC2 mound building, we infer that the UDPR area was colonized at least c. $2000{ }^{14} \mathrm{C}$ yr BP. LDC2 and LDLG1 records constitute, thus far, the oldest evidence from archaeological research in the area (Bonomo et al., 2011). Although the colonization of neighbouring regions began in the late Pleistocene-early Holocene, c. $10,000{ }^{14} \mathrm{C}$ yr BP (e.g. Castiñeira, 2008; López Mazz, 2013; Prates et al., 2013; Schmitz and Jacobus, 2001), the populating of the area occurred after the last Holocene transgressive event c. $6000{ }^{14} \mathrm{C}$ yr BP, in relation to territorial availability (Cavallotto et al., 2005; Codignotto, 2004; Iriondo et al., 2007; Iriondo and Kröhling, 2008). Once the area reached its current geomorphological configuration, c. $2000{ }^{14} \mathrm{C}$ yr BP, occupational strategies carried out in UDPR were already consistent with a settlement system adapted to environments characterized by high hydrometeorological susceptibility. Accordingly, we infer that in periods of low water levels and/or hydrometeorological stability, pre-Hispanic inhabitants of the UDPR settled in both mounds and naturally elevated levees. During the occupation of levees (e.g. LDLG locality), the inhabitants carried out a number of activities in which the exploitation of certain faunal resources, particularly mammals, was predominant. During high water levels, they settled only in mound sites, represented here by LDC sites.

Integrated studies of LDLG, LDC and LTC localities support Politis and Bonomo's interpretations (2012) that GoyaMalabrigo occupation pattern included a wide network of settlements, which constituted an effective sociocultural response to the risks involved in the colonization of highly dynamic wetlands. In that sense, the occupation pattern of the area must have been based on different types of settlements, where main residential places were established at the most elevated areas of the landscape, which were rarely inundated except for periods of exceptional flooding. The most visible record of such practice is represented by the mounds of LDC and LTC localities. Complementarily, the pattern also included temporary settlements focused on the exploitation of specific resources, which were probably occupied during short periods of hydrological stability and low water levels.

\section{Acknowledgements}

We are grateful to Jordan family and Miguel Reynoso from the Pre-Delta National Park for their assistance in the field work. This article was translated by Ana Florencia Carotti. The views expressed in the paper are the sole responsibility of the authors.

\section{Funding}

This work was funded by the National Geographic Society's Committee for Research and Exploration through research grant number 9328-13, the Consejo Nacional de Investigaciones Cientificas y Tecnicas of Argentina (CONICET), and the Argentinian Agencia Nacional de Promocion Cientifica y Tecnologica (ANPСyT) (PICT-0665). 


\section{References}

Baigún C, Puig A and Minotti PG (2008) Resource use in the Parana River Delta (Argentina): Moving away from an ecohydrological approach? Ecohydrology and Hydrobiology 8: 245-262.

Bastourre ML (2014) Estudios arqueofaunísticos en el Delta Superior del Paraná: El sitio los Tres Cerros 1. Revista Chilena de Antropología 3: 109-115.

Bates RG (1983) Determination of $p H$. New York: Wiley.

Blanco DE and Méndez FM (2010) Endicamientos y terraplenes en el Delta del Paraná. Situación, efectos ambientales y marco jurídico. Buenos Aires: Fundación Humedales/Wetlands International.

Bó R (2006) Ecorregión Delta e Islas del Paraná. In: Brown A, Martinez Ortiz U and Acerbi Mand Corcuera J (eds) Situación Ambiental Argentina 2005. Buenos Aires: Fundación Vida Silvestre, pp.131-143.

Bó R and Malvárez A (1999) Las inundaciones y la biodiversidad en humedales. Un análisis del efecto de eventos extremos sobre la fauna silvestre. In: Malvárez A (ed.) Tópicos sobre humedales subtropicales y templados de Sudamérica. Montevideo: Oficina Regional de Ciencia y Tecnología de la UNESCO para America Latina y el Caribe, pp. 140-161.

Bonetto A and Orfeo O (1984) Caracteres sedimentológicos de la carga en suspensión del río Paraná entre Confluencia y Esquina (Prov. de Corrientes). Revista de la Asociación Argentina de Mineralogía, Petrología y Sedimentología 15: 51-61.

Bonomo M (2012) Historia Prehispánica de Entre Ríos. Buenos Aires: Fundación de Historia Natural 'Félix de Azara'.

Bonomo M, Politis G and Gianotti C (2011) Montículos. Jerarquía social y horticultura en las sociedades indígenas del Delta del Río Paraná (Argentina). Latin American Antiquity 22: 297-333.

Bonomo M, Politis G, Silva C et al. (2016) Estado actual de las investigaciones en la localidad arqueológica Laguna de los Gansos (Diamante, Entre Ríos). Revista del Museo de Antropología 9(2): 51-66.

Bracco R, Montaña J, Nadal O et al. (2000) Técnicas de construcción y estructuras monticulares, termiteros y cerritos: de lo analógico a lo estructural. In: Durán A and Bracco R (eds) Arqueología de las Tierras Bajas. Montevideo: Ministerio de Educación y Cultura, pp. 285-300.

Camilloni IA and Barros VR (2003) Extreme discharge events in the Paraná River and their climate forcing. Journal of Hydrology 278: 94-106.

Capdepont I and Pintos S (2006) Manejo y aprovechamiento del medio por parte de los grupos constructores de montículos: Cuenca de la laguna de Castillos, Rocha, Uruguay. Relaciones de la Sociedad Argentina de Antropología 31: 117-132.

Capdepont I, Castiñeira C, del Puerto L et al. (2016) Desarrollo de las ocupaciones humanas durante el Holoceno en la cuenca de la Laguna de Castillos (Uruguay): sintesis y actualizacion de las investigaciones arqueologicas. Tessituras 4: 53-93.

Carver R (1971) Procedures in Sedimentary Petrology. New York: Wiley-Interscience.

Castiñeira C (2008) Aspectos de la colonización humana prehistórica del noroeste de Uruguay. PhD Thesis, Facultad de Filosofía y Letras, Universidad de Buenos Aires.

Castiñeira C and Piñeiro G (2000) Análisis estadístico textural para el estudio de las columnas estratigráficas de las excavaciones I y II del Bañado de los Indios. In: Durán A and Bracco R (eds) Arqueología de las tierras bajas. Montevideo: Ministerio de Educación y Cultura, pp. 467-478.

Castiñeira C, Blasi A, Bonomo M et al. (2014) Modificación antrópica del paisaje durante el Holoceno tardío: las construcciones monticulares en el delta superior del río Paraná. Revista de la Asociación Geológica Argentina 71: 33-47.
Castiñeira C, Blasi A, Politis G et al. (2013) The origin and construction of pre-Hispanic mounds in the Upper Delta of the Paraná River (Argentina). Archaeological and Anthropological Sciences 5: 37-57.

Castiñeira C, Capdepont I, del Puerto L et al. (2015) Aportes de la geoarqueología para el estudio de la variabilidad constructiva prehispánica de cerritos del este uruguayo y el delta del Paraná. In: Rubin de Rubin J, Favier Dubois C and da Silva T (eds) Geoarqueologia na America do Sul. Goiânia: Editora da PUC, pp. 55-91.

Cavallotto J (1995) Evolución Geomorfológica de la llanura costera del margen sur del Río de la Plata. PhD Thesis, Facultad de Ciencias Naturales y Museo, Universidad Nacional de La Plata.

Cavallotto J, Violante R and Colombo F (2005) Evolución y cambios ambientales de la llanura costera de la cabecera del río de la Plata. Revista de la Asociación Geológica Argentina 60: 353-367.

Cavallotto J, Violante R and Parker G (2004) Sea level fluctuation during the last 8600 yrs in the Río de la Plata (Argentina). Quaternary International 114: 155-165.

Ceruti C (2003) Entidades culturales presentes en la cuenca del Paraná Medio (margen enterriana). Mundo de Antes 3: 111-134.

Codignotto J (2004) Delta. Evolución Geológica. In: Atlas ambiental de Buenos Aires. Available at: www.atlasdebuenosaires. gov.ar/aaba/index.php?option=com_content\&task=view\&id $=214 \&$ ltemid $=99$ (accessed 20 January 2012).

Colobig MM, Sánchez JO and Zucol A (2015) Análisis de macrorrestos vegetales en el sitio arqueológico Los Tres Cerros 1 (isla Las Moras, Victoria, Entre Ríos). Revista del Museo de Antropología 8(1): 115-124.

Colobig MM, Zucol A, Bonomo M et al. (2014) Estudios arqueobotánicos del sitio Laguna de los Gansos 1 (Delta Superior del río Paraná, Argentina): análisis de microrrestos vegetales en materiales cerámicos. In: Workshop Micro Paleoetnobotánica: Relevancia de una Red Interdisciplinaria de Investigaciones en Fitolitos y Almidones, La Paloma, 8-12 December (unpublished).

Day P (1965) Particle fractionation and particle-size analysis. In: Black C (ed.) Methods of Soil Analysis. Madison, WI: American Society of Agronomy, Inc., pp. 545-567.

Di Prado V (2015) Estudio comparativo de las prácticas de elaboración y uso de la alfarería prehispánica del centro-este de Argentina desde una perspectiva macrorregional. $\mathrm{PhD}$ Thesis, Facultad de Ciencias Naturales y Museo, Universidad Nacional de La Plata, La Plata.

Drago E, Amsler M and Paira A (2014) Upstream growth of sandbars and islands in the Paraná river. Aqua-LAC 6: 1-7.

Durán A and Bracco R (eds) (2000) Arqueología de las Tierras Bajas. Montevideo: Ministerio de Educación y Cultura.

Edith R (1985) Theoretical and practical considerations in the analysis of anthrosols. In: Rapp G and Gifford J (eds) Archaeological Geology. New Haven, CT: Yale University Press, pp. 155-190.

Erickson C (2006) The domesticated landscapes of the Bolivian Amazon. In: Balée W and Erickson C (eds) Time and Complexity in Historical Ecology: Studies in the Neotropical Lowlands. New York: Columbia University Press, pp. 235-278.

Folk R (1954) The distinction between grain size and mineral composition in sedimentary rock nomenclature. Journal of Geology 62: 344-359.

Gaspary F (1950) Investigaciones arqueológicas y antropológicas en un 'cerrito' de la Isla Los Marinos (Pcia. De Entre Ríos). Publicaciones del Instituto de Arqueología, Lingüística y Folklore 'Dr. Pablo Cabrera' 23: 1-66.

Heiri O, Lotter AF and Lemcke G (2001) Loss on ignition as a method for estimating organic and carbonate content in 
sediments: Reproducibility and comparability of results. Journal of Paleolimnology 25: 101-110.

Herzer H, Caputto MG and Celis A (2004) Análisis regional: Cuenca del Río Paraná. In: Gestión de Riesgos de desastre ENSO en América Latina. Buenos Aires: Centro de Estudios Sociales y Ambientales, pp. 3-40.

Hogg A, Quan H, Blackwell P et al. (2013) SHCal13 southern hemisphere calibration, 0-50,000 years cal BP. Radiocarbon 55: $1889-1903$.

Iriarte J, Holst I and Marozzi O (2004) Evidence for cultivar adoption and emerging complexity during the mid-Holocene in the La Plata Basin. Nature 432: 561-562.

Iriondo M (2004) The littoral complex at the Paraná mouth. Quaternary International 114: 143-154.

Iriondo M and Kröhling D (2008) Cambios ambientales en la cuenca del río Uruguay: desde dos millones de años hasta el presente. Santa Fe: Universidad Nacional del Litoral.

Iriondo M, Parma M and Paggi J (2007) The Middle Paraná River: Limnology of a Subtropical Wetland. New York: Springer-Verlag.

López Mazz JM (1992) Aproximación a la génesis y desarrollo de los cerritos de la zona de San Miguel (Depto. de Rocha). In: López JM and Sanz M (eds) Ediciones del Quinto Centenario. Montevideo: Facultad de Humanidades y Ciencias de la Educación, pp. 60-80.

López Mazz JM (2013) Early human occupation of Uruguay: Radiocarbon database and archaeological implications. Quaternary International 301: 94-103.

Malvárez A (1999) El Delta del Río Paraná como mosaico de humedales. In: Malvárez A (ed.) Tópicos sobre humedales subtropicales y templados de Sudamérica. Montevideo: Taller ecologista, pp. 35-53.

Minotti P and Borro M (2011) Pulsos de inundación y seca. In: Kandus P, Minotti P and Borro M (eds) Contribuciones al conocimiento de los humedales del Delta del Río Paraná: herramientas para la evolución de la sustentabilidad ambiental. San Martín: UNSAM, pp. 8-9.

Naue G (1973) Dados sobre o estudo dos cerritos na área meridional da Lagoa dos Patos, Rio Grande, R.S. Revista Veritas 71: 246-269.

Neiff J and Malvárez A (2004) Grandes humedales fluviales. In: Malvárez A and Bó R (eds) Bases ecológicas para la clasificación de humedales en Argentina. Buenos Aires: FCEYN - UBA, pp. 77-83.

Parker G and Marcolini S (1992) Geomorfología del Delta del Paraná y su extensión hacia el Río de La Plata. Revista de la Asociación Geológica Argentina 47: 243-250.

Piñeiro G, Castiñeira C and Fernández G (1999) Aplicaciones del estudio paleoambiental a las investigaciones arqueológicas Laguna de Castillos (Rocha, Uruguay). In: Bixio B and Berberián E (eds) Libro de resúmenes XIII Congreso Nacional de Arqueología Argentina, Cordobá, Argentina, 5-8 November 2014, pp. 308-309.

Politis G and Bonomo M (2012) La entidad arqueológica GoyaMalabrigo (Ríos Paraná y Uruguay) y su filiación Arawak. Boletín de la Sociedade de Arqueologia Brasileira 25: 10-46.

Politis G, Bonomo M, Castiñeira C et al. (2011) Archaeology of the Upper Delta of the Paraná River (Argentina): Mound construction and anthropic landscapes in the Los Tres Cerros locality. Quaternary International 245: 74-88.

Prates L, Politis G and Steele J (2013) Radiocarbon chronology of the early human occupation of Argentina. Quaternary International 301: 104-122.
Quintana R and Bó R (2010) Caracterización general de la región del Delta del Paraná. In: Blanco DE and Méndez FM (eds) Endicamientos y terraplenes en el Delta del Paraná. Situación, efectos ambientales y marco jurídico. Buenos Aires: Fundación Humedales/Wetlands International, pp. 5-13.

Ramonell C, Latrubesse E and Pereira M (2011) Procesos y ritmos de construcción actuales de la planicie aluvial del río Paraná Medio, geoformas resultantes. In: Leanza H, Arregui $\mathrm{C}$, Carbone $\mathrm{O}$ et al. (eds) Libro de Actas del XVIII Congreso Geológico Argentino, Neuquén, Argentina, 2-6 May 2011, pp. 1247-1248.

Ré M and Menendez A (2004) Estudio de los corredores de flujo del Río de la Plata interior a partir del modelo de circulación $R P P-2 D$. Ezeiza: Instituto Nacional del Agua.

Ribeiro B and Milheira R (2015) A cerâmica dos cerritos no Pontal da Barra - Pelotas/RS: por uma (necessária) revisão conceitual da tradição Vieira. Teoria e sociedade 23: 95-124.

Rinaldi V, Abril E and Clariá J (2006) Aspectos geotécnicos fundamentales de las formaciones del delta del río Paraná y del estuario del Río de la Plata. Revista internacional de desastres naturales, accidentes e infraestructura civil 6(2): 131-148.

Rostain S (2010) Pre-Columbian earthworks in coastal Amazonia. Diversity 2(3): 331-352.

Salles Machado J (2005) Montículos Artificiais na Amazônia Central: Um estudo de caso do sitio Hatahara. $\mathrm{PhD}$ Thesis, Museu de Arqueologia e Etnologia da Universidade de São Paulo.

Sánchez J, Colobig M and Zucol A (2013) Primeros resultados sobre el uso prehispánico de los vegetales en el sitio arqueológico Los Tres Cerros 1 (Victoria, Entre Ríos, Argentina): análisis del registro biosilíceo. Darwiniana 2: 201-219.

Scabuzzo C, Ramos van Raap A, Bonomo M et al. (2015) Estudios bioarqueológicos en el sitio Los Tres Cerros 1 (Delta Superior del río Paraná, Entre Ríos, Argentina). Boletim do Museu Paraense Emílio Goeldi, Ciências Humanas 10(2): 487-518.

Schmitz A and Jacobus A (2001) The antiquity of the peopling of southern Brasil. Current Research in the Pleistocene 18: $17-19$.

Schmitz P, Naue G and Basile-Beker I (1991) Os aterros dos campos do sul: a Tradição Vieira. In: Kern A (ed.) Arqueología Prehistórica de Rio Grande do Sul. Porto Alegre: Mercado Aberto, pp. 221-250.

Silva C (2014) Tecnología cerámica del sitio Laguna de los Gansos 1 (Dpto. Diamante, Entre Ríos). In: Leiteri F, Cocco $\mathrm{G}$ and Fritegotto G (eds) VII Congreso de Arqueología de la Región Pampeana Argentina, Santa Fe, Argentina, 5-8 November 2014.

Suárez X and Gianotti C (2013) Earthen mound formation in the Uruguayan lowlands (South America): Micromorphological analyses of the Pago Lindo archaeological complex. Journal of Archaeological Science 40: 1093-1107.

Vizia C, Spiaggi E, Stancich E et al. (2010) Humedales del Paraná. Biodiversidad, usos y amenazas en el Delta Medio. Rosario: Inercia Comunicaciones.

Willard H, Merrit L and Dean J (1974) Instrumental methods of analysis. New York: D. van Nostrand Company.

Zárate M, González M, Flegenheimer N et al. (2002) Sitios arqueológicos someros: El concepto de sitio en estratigrafía y sitio de superficie. Cuadernos del INAPL 19: 635-653.

Zhao Z and Pearsall D (1998) Experiments for improving phytolith extraction from soils. Journal of Archaeological Science 25: 587-598. 